TURIZAM

Volume 16 , Issue 1

29-39 (2012)

\title{
Researching Connection between Service Orientation and Work Satisfaction: A Study of Hotel Employees (Novi Sad, Serbia)
}

Marko D. Petrović* , Jelica Marković*

Received: November 2011 | Accepted: January 2012

\begin{abstract}
In recent years, researches of service industry put in the centre of many papers the phenomena of the relation between service orientation and work (job) satisfaction of the employees in the service sector. It have been analyzed many factors that affect the quality of hotel services and opportunities to improve service processes. One of the most important factor of service quality in the hospitality industry is service orientation of employees. On the other side, if the employees are satisfied with the work they are motivated to satisfy customer needs. The purpose of the paper is to study connections and differences among the hotel employees in service orientation and work satisfaction. To determine these issues, we used service orientation scale, developed by Dienhart, Gregoire, Downey and Knight (1992) and work satisfaction scale developed by Lytle (1994). We expected three factor solution for service orientation scale and uni-factor solution for work satisfaction. The results will be discussed and some practical recommendations will be given.
\end{abstract}

Key words: city type hotels, service orientation, work satisfaction, hotel employees, Novi Sad

\section{Introduction}

Hotel enterprise, as an important part of hospitality, represents combination of spatial and functional service of accommodation, including food and beverages services as well as all the other supporting services. What makes hotel industry specific and separates it from all other sectors of hospitality industry is the possibility to provide accommodation, with over night stay (Kosar, 2002). In recent years, there have been many indications of the importance of human resources (HR) management in hospitality and tourism, and there is a significantly increased emphasis on proper selection of employees (Kim, Leonga, and Lee, 2005; Bolton and Boyd, 2003; Byrne, I986; Dronfield and Soto, I982; Gabriel, I988; Hoque, 2000; Mars and Nicod, 1984). Therefore, employees are becoming the center of interest of tourism experts and management of hotel enterprises (Čačić, I998; Čerović, 2002; Kosar, 2002). Considering this together, with the fact that hotel industry implies working with people,

\footnotetext{
* Department of Geography, Tourism and Hotel Management, Faculty of Sciences, University of Novi Sad, Trg
} Dositeja Obradovica 3, 21000 Novi Sad, Serbia, Corresponding author: m_petrovic86@yahoo.com 
studying hospitality concepts, such as service orientation and work (job) satisfaction of the employees, becomes essential.

Having gone through many phases of transformation of organizational components, global hotel industry today has significantly change general conception of hotel business. Similar situation occurs in Serbia. Hotel companies in Serbia are going through transitional (i.e. economic, organizational, psychological, etc.) changes that affect the business in general, as well as the relationship of the company towards employees. This change causes already detectable differences that have not yet been thoroughly examined by the scientific community in Serbia and in the world as well. In our case, the study will include Io hotel objects in Novi Sad, Serbia. We will investigate relation between two hospitality dispositional variables: service orientation and work satisfaction.

\section{Service orientation}

Service orientation (SO) could be described as the ability to be useful, thoughtful, considerate and cooperative in providing services at the individual level (Dienhart and colleagues, I992). On the other side, authors such as Lytle $(\mathrm{I} 998,459)$ defined service orientation as "an organization-wide embracement of a basic set of relatively enduring organizational policies, practices and procedures intended to support and reward service-giving behaviors that create and deliver service excellence". Through the purpose of service orientation, organization interprets the company philosophy and culture of business to its employees in order to improve the quality of the provided adequate service.

Service orientation of employees is determined by many factors - from the work environment, work demands, interpersonal relationships within the organization to financial and personal satisfaction. Recent researches show that during the consumption of certain hotel services, employee treatment of customers is the most important issue (Hartline and Ferrell, I996; Nikolić, 2006; Galičić and Ivanović, 2008). Consequences of service orientation are expressed in terms of work satisfaction of employee (Jaworski and Kohli, I993; Lee, Park and Yoo, I999), and turnover that employees make (Lahey, 1984).

There are researches that show the role of service orientation in strengthening competitive advantages (Schneider and Bowen, I985; Dienhart et al., I992; Kim, et al., 2005). The authors considered that employees should have competence to be cooperative and thoughtful in providing hotel services at the personal level, and most importantly, to have individual access to each guest in the hotel, so they could provide quality service. Employees in hotel industry should have adequate knowledge and skills in order to provide not only the expected quality, but also additional quality service to the guests (Blešić, Popov-Raljić and Romelić, 2007), as they are definitely the most important issue in evaluating hotel service quality. Numerous studies have shown that kindness and accessibility of staff are more important to guests than competence and technical organization (Čerović, 20O2; Galičić and Ivanović, 2008). The attitudes and behavior of employees results in the perception of service quality by customers (Hartline and Ferrell, I996). Establishing relationships with service users is crucial to building loyalty and improving the service delivery process (Nikolić, 2006; Galičić and Ivanović, 2008). Certain psychological characteristics (sociability, openness, agreeableness, etc.) enable employees to meet with increasingly complex demand in travel industry.

In the field of tourism and hospitality, results of Dienhart and colleagues (I992) suggest that service orientation is comprised of three components: organizational support, customer 
focus, and service under pressure, but also suggest that increasing employees' work satisfaction (with work involvement and work security) is involved in the improving of their overall service orientation. They conclude that there are positive relationships between work satisfaction and customer focus, employees' favorable perceptions of work involvement and work security.

The role of emotions in the service orientation is crucial. Hochschild (1983) argued that service agents (e.g. hotel employees) are expected to experience and express certain feelings during service interactions. The concept of service orientation implies that workers should be able to display all the emotions that are desired by their supervisors and consumers (O'Connor, Trinh and Shewchuk, 2000). Emotional labor is defined as display of expected emotions by service agents during service encounters, and since service context involves face-to-face interactions it is important to explore emotions and emotional labor in service orientation context (Ashforth and Humphrey, I993). Hochschild (I983) claimed that service providers, comply with expression norms through surface acting, self-expression, expression of spontaneous and genuine emotion. However, the presence of a service agent, such as hotel employee, may prime expectations of good service that cannot be met, and emotional labor may trigger emotive dissonance and impair one's sense of authentic self.

\section{Work Satisfaction}

The second important issue of our research is employees' work satisfaction (WS) in the observed hotels. Odom, Boxx and Dunn (I990, I59) defined work satisfaction as "the extent to which a worker feels positively or negatively about his or her job" and four years later, Lytle's (1994) research indicates that work satisfaction is uni-dimensional variable. Work satisfaction is an important predictor of quality of hotel services. There are many determinants of work satisfaction and certain research even suggest that work satisfaction may be genetically determined and remains constant over a five years period though many segments of business change (Arvey, Bouchard, Segal, and Abraham, I989; George, 2000; Staw, Bell and Clausen, I986).

In a service business, work satisfaction ensures that employees treat service users, i.e. hotel guests with maximum respect (Arnett, Laverie and McLane, 2002). Because of the importance of contact with service users due to the development of relations with them, the employee's work satisfaction is a major concern for service companies, i.e. hotels that want to keep a large number of loyal customers. Other authors, such as Jerome and Kleiner (I995), agree that enterprises which are working to improve employee's work satisfaction, motivation and work dedication, can expect long-term benefits of corporate success, loyalty and productivity of employees. Some authors showed that work satisfaction also has a positive correlation with a commitment to organizations (Humphreys and Williams, I996; Blešić, Ivkov-Džigurski, Dragin, Ivanović and Pantelić, 2OII) and performance (Birnbaum and Sommers, I993; Babin and Boles, 1996). Shaw (1999) claimed that there is a strong negative relationship between the level of turnover and work dissatisfaction. Others believe that if employees are dissatisfied with their work, it is more likely that they will make no expectations and eventually leave the organization (Mobley, 1977).

Management of hotel enterprises which wants to create satisfied customers, should follow these guidelines (Galičić and Ivanović, 2008):

- The existence of job satisfaction of employees, 
- Accessibility to employees,

- Employees in direct contact with guests empowered to solve all the problems and

- Responsible access to the guests.

Nowadays, there are many models (Hunt and Chonko, I984; Lawler and Hackman, I97I; Lawler and Stuttle, I973; Lucas, Parasuraman, Davis, and Enis, I987; Sujan, I986; Teas, I983) which create satisfied (hotel) employees and improved quality of operations. Increase in the responsibility of the employee creates a greater commitment and sense of usefulness and importance of the employee and the organization. More power leads to timely resolution of unforeseen problems in working with guests, but is also creates satisfaction. Employees should be aware of changes and innovations in business enterprises such as hotels.

\section{Method and Data}

The population for our research consists of II5 employees of IO city type hotels in Novi Sad (“Aurora”, "Park”, “Zenit”, “Mediteraneo”, “Gimnas”, “Centar”, “Vojvodina”, "Putnik”, "Novi Sad" and "Panorama”). Employees were selected from eight segments of hotel's organizational structure (Front Office/Reception, Human Resources Management, Restaurant, Administration and Accounts, Bars, Housekeeping, Executive Management and Kitchen). While sampling, we covered all categorizations levels of hotels (from one star, i.e. "Aurora", to five star hotels, i.e. "Park"). The research was carried out from March until June 2OII.

Table I presents the distribution of respondents' work position, gender, age, educational background and residence. On the basis of survey research, it can be concluded that among the employee apparent significantly higher number of female (nearly 59\%), while another $4 \mathrm{I} \%$ of respondents are men. It is interesting to say, that the ratio is almost the same as

Table 1 Sample characteristics (\%)

\begin{tabular}{|l|r|}
\hline Work Position: & 22.5 \\
Employer & 77.5 \\
Staff & \\
\hline Gender: & 41.1 \\
Men & 58.9 \\
Women & \\
\hline Age: & 11.3 \\
- 20 years & 30.2 \\
$21-30$ years & 21.1 \\
31-40 years & 13.2 \\
41-50 years & 18.2 \\
51-60 years & 6.0 \\
61+ years & \\
\hline Education: & 10.3 \\
Primary School & 45.7 \\
High School & 36.2 \\
University Degree & 7.8 \\
Postgraduate Degree & \\
\hline Residence: & 75.1 \\
City of Novi Sad & 22.4 \\
Surrounding area & 2.5 \\
Other settlements & \\
\hline
\end{tabular}

for the entire population of hospitality service workers in Serbia of whom $56 \%$ are women and 44\% are men (Čačić, I998; Čerović, 2OO2).

Among the respondents, approximately $75 \%$ reside in the territory of Novi Sad and the remainder lives in surrounding smaller towns. Only a few respondents are from the other country regions (2.5\%). Most (30.2\%) of the respondents were in their 2O's; the next largest group (2I.I\%) of employees were in their 30's. When analyzing the structure of respondents by working position, results clearly show higher proportion of employees in the executive affairs (77.5\%), than employees in managerial positions (22.5\%). Further results present the educational structure where clearly show the highest percentage of respondents (56\%) has elementary and high school diplomas; $44 \%$ had a college and postgraduate diploma.

In our research, questionnaire consists of three parts: socio-demographic characteristics, service orientation and work satisfaction of respondents. In the last two scales, the respondents express their opinion about items on the five-point Likert' scale (from I - completely agree to 5 - completely disagree). 
Table 2 Service Orientation of Hotel Employee $\left(\mathrm{SO}_{1-\vartheta}\right)$

\begin{tabular}{|l|l|}
\hline $\mathrm{SO}_{1}$ & Interacting with customers is enjoyable. \\
\hline $\mathrm{SO}_{2}$ & It is important to me that the customer is satisfied. \\
\hline $\mathrm{SO}_{3}$ & The employees at my hotel provide excellent service. \\
\hline $\mathrm{SO}_{4}$ & My manager encourages me to provide better service. \\
\hline $\mathrm{SO}_{5}$ & The training which I received prepared me to provide excellent service. \\
\hline $\mathrm{SO}_{6}$ & Customers treat me with respect. \\
\hline $\mathrm{SO}_{7}$ & At peak hours, we are so busy that we cannot provide excellent service. \\
\hline $\mathrm{SO}_{8}$ & Our service procedures make it easy for me to give excellent service. \\
\hline $\mathrm{SO}_{9}$ & My manager expects us to always follow procedures, even if it means giving less than excellent service. \\
\hline
\end{tabular}

Source: Dienhart et al., 1992 in Kim, Leonga and Lee, 2005, 178

Table 3 Work Satisfaction of Hotel Employee $\left(W_{1-5}\right)$

\begin{tabular}{|l|l|}
\hline WS1 & I consider my work pleasant. \\
\hline WS2 & I feel fairly-well satisfied with my present work. \\
\hline$W_{3}$ & I definitely like my work. \\
\hline$W_{4}$ & My work is pretty interesting. \\
\hline$W_{5}$ & I find real enjoyment in my work. \\
\hline
\end{tabular}

Source: Lytle, 1994 in Kim, Leonga and Lee, 2005, 179

\section{Results and Discussion}

In interpretation of our results, we confirmed previous studies, where it found that work satisfaction has uni-dimensional structure, so we simply summed the answers in the form of a composite score. In the case of service orientation, we extracted three factors with eigenvalue higher that I, which describe it: organizational support, customer focus and service under pressure.

Table 4. Service Orientation (orthogonal rotation)

\begin{tabular}{|c|c|c|}
\cline { 2 - 3 } \multicolumn{1}{c|}{} & Eigenvalue & \% Total Variance \\
\hline Factor 1 & 3,032 & 33,687 \\
\hline Factor 2 & 1,362 & 15,132 \\
\hline Factor 3 & 1,052 & 11,689 \\
\hline
\end{tabular}

The Factor I explains about 38\% of the total variance, Factor 2 covers additional $12 \%$ of the variance, while the Factor 3 explains nearly II\%. The total percentage of explained variance is about $60 \%$.

In Factor I, the variable SO8 has the highest positive correlation with Factor I (factor loading $=$ 0.794). This means that organizational support is highly correlated with the establishment of service procedures that facilitates the provision of excellent hotel services. Item $\mathrm{SO}_{4}$ also highly correlated with Factor I, which clearly shows that encouragement by managers in providing quality services is an important part of organizational support. On the other side, SO6 loads onto Factor I as well, which leads to an unusual conclusion where a 
Table 5. Factor Analysis - Service Orientation*

\begin{tabular}{|c|c|c|c|c|}
\hline & & Factor 1 & Factor 2 & Factor 3 \\
\hline $\mathrm{SO}_{1}$ & Interacting with customers is enjoyable. & 0,301 & 0,663 & $-0,164$ \\
\hline $\mathrm{SO}_{2}$ & It is important to me that the customer is satisfied. & $-0,008$ & 0,868 & 0,078 \\
\hline $\mathrm{SO}_{3}$ & The employees at my hotel provide excellent service. & 0,354 & 0,575 & $-0,217$ \\
\hline $\mathrm{SO}_{4}$ & My manager encourages me to provide better service. & 0,773 & 0,082 & $-0,172$ \\
\hline $\mathrm{SO}_{5}$ & $\begin{array}{l}\text { The training which I received prepared me to provide excellent } \\
\text { service. }\end{array}$ & $-0,028$ & 0,039 & $-0,891$ \\
\hline S06 & Customers treat me with respect. & 0,708 & 0,400 & 0,027 \\
\hline $\mathrm{SO} 7$ & $\begin{array}{l}\text { At peak hours, we are so busy that we cannot provide excellent } \\
\text { service. }\end{array}$ & $-0,339$ & 0,208 & 0,400 \\
\hline SO8 & Our service procedures make it easy for me to give excellent service. & 0,794 & 0,055 & 0,171 \\
\hline SO9 & $\begin{array}{l}\text { My manager expects us to always follow procedures, even if it } \\
\text { means giving less than excellent service. }\end{array}$ & $-0,618$ & $-0,031$ & 0,418 \\
\hline
\end{tabular}

*We bolded only values larger than 0.4

large number of the respondents believe that even respect from the service consumers, i.e. hotel guests, leads to better organizational support in the hotel company. In the end, expectation of the manager to follow blindly procedure, even if the service is less than expected, correlates negatively with this factor. It seems that employees believe that procedure is important for the organization, but quality service needs to be a priority.

Item $\mathrm{SO}_{2}$ has the strongest loading onto Factor 2 (factor loading $=0.868$ ). Items SOI, $\mathrm{SO}_{3}$ and $\mathrm{SO} 6$, also have strong loadings onto this dimension, i.e. the enjoyment and respect during the contact with the hotel guests is of very important for the observed factor, as well as providing excellent service to guests. These results indicate expected relations when it comes to customer focus, and we can easily conclude what are the necessary measures to raise this dimension in hotel facilities.

Factor 3 is highly negatively correlated with the training which hotel staff goes through, in order to provide excellent service (factor loading = -0.89I). It seems that staff at Novi Sad' hotels claims that they do not have adequate training (on the work place) which will provide the best possible hotel service. Such an alarming indicator should be high priority of all hotel managers if they want to increase turnover and quality of hotel services.

Table 6 presents average values of correlation between scales service orientation $\left(\mathrm{SO}_{\mathrm{I}-9}\right)$ and work satisfaction $\left(\mathrm{WS}_{\mathrm{I}-5}\right)$. These values are important because it will show level of statistically significant between observed dispositional variables.

Table 6. Average values of correlation

\begin{tabular}{|c|c|c|c|}
\hline & & Average scale SO & Average scale WS \\
\hline \multirow[t]{3}{*}{ Average scale SO } & Pearson Correlation & 1 &, $\left.487^{(\star *}\right)$ \\
\hline & Sig. (2-tailed) & . &, 000 \\
\hline & $\mathrm{N}$ & 155 & 155 \\
\hline \multirow[t]{3}{*}{ Average scale WS } & Pearson Correlation &, $\left.487^{(*}\right)$ & 1 \\
\hline & Sig. (2-tailed) &, 000 & . \\
\hline & $\mathrm{N}$ & 155 & 155 \\
\hline
\end{tabular}

** Correlation is significant at the 0.01 level (2-tailed) 
From the correlation matrix it could be concluded that two observed constructs moderately correlated and that the coefficient of the correlation between Average scale SO and Average scale WS are equal to 0.487, with significance level less of O.OI ( $p<0 . \mathrm{OI}, \mathrm{r}=0.49)$. This obviously means that the correlation coefficient is significantly different from zero.

Table 7 shows that there are light statistically significant correlations between items of the constructs SO and WS. From the correlation matrix it can be concluded that the correlation coefficient between the variables SO6 and variables WS 4 is equal to 0.455 with a significance level of less than O.OI, which means that the correlation coefficient are different from zero. Similar relationship is with the observed variable and WS5, which is equal to 0.540 , which also confirms the above conclusion. These correlations suggest that the relationship between feelings of respect by the customer very highly correlated with the interesting work but also with pleasure that employees find at work.

Table 7 General correlation matrix based on the overall sample

\begin{tabular}{|c|c|c|c|c|c|c|}
\hline & & WS1 & WS2 & WS3 & WS4 & $\mathrm{WS}_{5}$ \\
\hline \multirow[t]{3}{*}{$\mathrm{SO}_{1}$} & Pearson Correlation & ,152 &, $396\left(^{\star \star}\right)$ &, $282\left({ }^{\star}\right)$ &, $\left.391{ }^{* *}\right)$ &, $443(* *)$ \\
\hline & Sig. (2-tailed) &, 269 &, 003 &, 037 &, 003 &, 001 \\
\hline & $\mathrm{N}$ & 155 & 155 & 155 & 155 & 155 \\
\hline \multirow[t]{3}{*}{$\mathrm{SO}_{2}$} & Pearson Correlation &, $271\left(^{*}\right)$ &, $\left.345^{(* *}\right)$ &, 237 &, $309\left(^{*}\right)$ &, 214 \\
\hline & Sig. (2-tailed) &, 045 &, 010 &, 081 &, 022 &, 117 \\
\hline & $\mathrm{N}$ & 155 & 155 & 155 & 155 & 155 \\
\hline \multirow[t]{3}{*}{$\mathrm{SO}_{3}$} & Pearson Correlation &, 256 &, $403(* *)$ &, 244 &, 131 &, $302\left(^{\star}\right)$ \\
\hline & Sig. (2-tailed) &, 060 &, 002 & ,073 &, 339 &, 025 \\
\hline & $\mathrm{N}$ & 155 & 155 & 155 & 155 & 155 \\
\hline \multirow[t]{3}{*}{$\mathrm{SO}_{4}$} & Pearson Correlation &, $390(* *)$ &, $\left.439^{(* *}\right)$ &, $361(* \star)$ &, $430(* *)$ &, $402(* *)$ \\
\hline & Sig. (2-tailed) &, 003 &, 001 &, 007 &, 001 &, 002 \\
\hline & $\mathrm{N}$ & 155 & 155 & 155 & 155 & 155 \\
\hline \multirow[t]{3}{*}{$\mathrm{SO}_{5}$} & Pearson Correlation &,- 098 &,- 080 & ,024 &, 028 &, 062 \\
\hline & Sig. (2-tailed) &, 478 &, 560 &, 862 &, 840 & ,651 \\
\hline & $\mathrm{N}$ & 155 & 155 & 155 & 155 & 155 \\
\hline \multirow[t]{3}{*}{ SO6 } & Pearson Correlation &, $\left.377^{\star \star \star}\right)$ &, $409(* *)$ &, $378(\star \star)$ &, $455\left(^{* *}\right)$ &, $540(* *)$ \\
\hline & Sig. (2-tailed) &, 005 &, 002 &, 004 &, 000 &, 000 \\
\hline & $\mathrm{N}$ & 155 & 155 & 155 & 155 & 155 \\
\hline \multirow[t]{3}{*}{$\mathrm{SO}_{7}$} & Pearson Correlation & ,098 &,- 041 &, 044 &, 071 &,- 086 \\
\hline & Sig. (2-tailed) & ,477 &, 764 &, 750 &, 608 &, 532 \\
\hline & $\mathrm{N}$ & 155 & 155 & 155 & 155 & 155 \\
\hline \multirow[t]{3}{*}{ SO8 } & Pearson Correlation &, $296\left(^{\star}\right)$ &, $451(* *)$ &, $\left.394^{\star \star *}\right)$ &, $322\left(^{*}\right)$ &, $423(* *)$ \\
\hline & Sig. (2-tailed) &, 028 &, 001 &, 003 &, 017 &, 001 \\
\hline & $\mathrm{N}$ & 155 & 155 & 155 & 155 & 155 \\
\hline \multirow[t]{3}{*}{ SOg } & Pearson Correlation &,$- 316\left(^{\star}\right)$ &,$\left.- 334{ }^{\star}\right)$ &,$- 375(\star \star)$ &,$- 397\left(^{\star \star}\right)$ &,$- 279\left(^{\star}\right)$ \\
\hline & Sig. (2-tailed) &, 019 &, 013 &, 005 &, 003 & ,039 \\
\hline & $\mathrm{N}$ & 155 & 155 & 155 & 155 & 155 \\
\hline
\end{tabular}

** Correlation is significant at the 0.01 level (2-tailed); bolded values are larger than 0.400 .

* Correlation is significant at the 0.05 level (2-tailed). 
From the correlation matrices it can be concluded that the correlation coefficient between the variables SO8 and variables WS2 is equal to 0.45I with a significance level of less than O.OI, which means that the correlation coefficient is different from zero. Hence, we can conclude that the establishment of service procedures that facilitate the provision of quality services is highly correlated with the employee's opinion that he feels fairly-well satisfied with his present work.

The following correlation matrix leads to the conclusion that the correlation coefficient between the variables WS2 and $\mathrm{SO}_{3}$, are equal to $\mathrm{O}_{4} \mathrm{O}_{3}$, and the relationship of the variable WS2 with the variable $\mathrm{SO}_{4}$ is equal to 0.439 and with the variable SO6 is equal to 0.409 . Hence, it can be concluded that the current work satisfaction highly correlate with a positive working environment, encouragement from managers, and appropriate behavior by clients (hotel guests).

From the above correlation matrix it can be observed that the correlation coefficient between the variables $\mathrm{WS}_{4}$ and $\mathrm{SO}_{4}$ equal to $0.43 \mathrm{O}$, from which we can conclude that attitudes about the interesting component in the work satisfaction highly correlated with the encouragement of the manager.

Finally, the correlation coefficient between the variables SOI and WS5 is equal to 0.443 with a significance level of less than O.OI, and the correlation coefficient between the variable WS5 and $\mathrm{SO}_{4}$ and $\mathrm{SO} 8$ are respectively $0.4 \mathrm{O} 2$ and 0.423 , and are significantly different from zero. These correlations suggest that the relationship between work pleasures of employees has high correlation with a pleasant interaction with the guests, with the encouragement of the manager and the appropriate service procedures established for the work.

The obtained results lead to the conclusion that service orientation through positive interaction with guests and superiors, adequate training and established procedures in service business is highly correlated to work satisfaction of employees which is reflected in comfort on the workplace, enjoyment and satisfaction that the work offers. This finding is highly important for future advancement of working processes in hotel enterprises in Novi Sad.

It is also good to mention that, the study was of adequate sample size, because from 22 hotel objects in Novi Sad (www.turizam.merr.gov.rs), we included Io objects, from all of five hotel categories. The number of respondents was II5 hotel employees from eight different segments of the organizational structure, from the lowest level to executive management. An author, such as Kosar (2002), claims that the average number of employees in the city type hotels is I5 persons. In our case, if we multiply that number by the number of hotel objects, we get amount of about 330 employees in the hotels of Novi Sad. Therefore, we can say that our sample was sufficient to make generalizations on the entire population (over I / 3 of the total number of hotel employees in hotel enterprises of Novi Sad was included in the survey).

\section{Concluding remarks}

On the basis of the above facts, it can be concluded that it is important to attach great importance to the problems of service orientation and work satisfaction of employees. This is due to turbulent changes in the tourism market and the increasingly complex demands of customers.

Travel services include not only fair and efficient service provided but contain a genuine human emotion which becomes the object of exchange. The last 20 years in the world, inten- 
sive work to identify the most important determinants of successful business, and experts agree that employees in this process have a crucial role.

Perception of service and the company, by the user of the service, depends on contact with the employee. The selection of high quality and compatible hotel management becomes imperative for business organizations.

In the future, it is necessary to pay more attention to HR development. The tourism industry must accept the fact that "happy employees create high-quality service" and accordingly take adequate measures to achieve this goal. Management of tourist organizations as the primary task must be set to examine the structure of investment in the tourism sector employees, based on several determinants, and on the basis of the results to develop methods, training programs and different ways to select good quality training and adequate staff.

It is necessary to understand and accept the importance of service orientation and work satisfaction of employees and monitoring the development of modern marketing concepts to respond to market demands and improve the current market position of Novi Sad's hotels.

\section{Acknowledgment}

The paper is supported by Ministry of Education and Science, Republic of Serbia (Grant I7602O).

\section{References}

Arnett, D. B., Laverie, D. A., McLane, C. 2002. Using job satisfaction and pride as internal-marketing tools. Cornell Hotel and Restaurant Administration Quarterly 43 (2), 87-96.

Arvey, R. D., Bouchard, T. J., Segal, N. L., Abraham, L. M. I989. Job satisfaction: Environmental and genetic components. Journal of Applied Psychology, 74, I87-I92.

Ashforth, B. E., Humphrey, R. H. 1993. Emotional labor in service roles: The influence of identity. Academy of Management Review, I8, 88-II5.

Babin, B.J., Boles, J.S., I996. The effects of perceived co-worker involvement and supervisor support on service provider role stress, performance and job satisfaction. Journal of Retailing 72 (I), 57-75.

Birnbaum, D., Somers, M.J. 1993. Fitting work performance into turnover model: an examination of the form of the job performance - turnover relationship and path model. Journal of Management 49 (2), I-II.

Blešić, I., Popov-Raljić, J., Romelić, J. 2007. Kvalitet usluga u novosadskim hotelijerskim objektima (Service Quality in Novi Sad's Hotel Objects). Turizam II, 2IO-2I3.

Blešić, I., Ivkov-Džigurski, A., Dragin, A., Ivanović, Lj., Pantelić, M. 2OII. Application of Gap Model in the Researches of Hotel Services Quality. Turizam I5 (I), 4O-52.

Bolton, S. and Boyd, C. 2003.Trolley dolly or skilled emotion manager? Work, Employment and Society, I7(2), 289-308.

Byrne, D. (1986). Waiting for change? Working in hotel and catering. London: Low Pay Unit.

Čačić, K. (I998). Poslovanje preduzeća u turizmu (Enterprises' business in tourism). Belgrade: Faculty of Economy.

Čerović, S. (20O2). Strategijski menadžment turističke privrede Srbije (Strategic management of tourism in Serbia). Belgrade: Želind. 
Dienhart, J.R., Gregoire, M.B., Downey, R.G., Knight, P.K. 1992. Service orientation of restaurant employees. International Journal of Hospitality Management, II (4), 33I-346.

Dronfield, L., Soto, P. (1982). Hardship hotel. London: Counter Information Services.

Eisenberger, R., Huntington, R., Hutchison, S., Sowa, D. 1986. Perceived organizational support. Journal of Applied Psychology, 7I, 500-507.

Gabriel, Y. (I988). Working lives in catering. London: Routledge and Keegan Paul.

Galičić, B., Ivanović, S. (2008). Menadžment zadovoljstva gosta (Guest Pleasure Management), Faculty of Management in Tourism and Hospitality, Opatija, Croatia.

George, J. M. 2000. Emotions and leadership: The role of emotional intelligence. Human Relations 53(8), IO27-IO55.

Hartline, M., Ferrell, O. I996. The management of customer-contact service employees: an empirical investigation. Journal of Marketing 20 (4), 52-70.

Hochschild, A. (1983). The managed heart: Commercialization of human feeling. Berkeley: University of California Press.

Hogan, R., Hogan, J. and Busch, C. I984. How to Measure Service Orientation. Journal of Applied Psychology 69, I67-I73.

Hoque, K. (2OOO). Human resource management in the hotel industry. Strategy, innovation and performance. London: Routledge.

Humphreys, M.A., \& Williams, M.R. (1996). Exploring the relative effects of salesperson interpersonal process attributes and technical product attributes on customer satisfaction. Journal of Personal Selling and Sales Management I6(3), 47-57.

Hunt, S. D., and Chonko, L. B. I984. Marketing and Machiavellianism. Journal of Marketing, 48, 3O-42.

Jaworski, B.J., Kohli, A.K. I993. Market orientation: antecedents and consequences. Journal of Marketing, 57 (3), 53-70.

Jerome, L., Kleiner, B.H. 1995. Employee morale and its impact on service: what companies do to create a positive service experience. Managing Service Quality 5 (6), 2I.

Kim, W. G., Leonga, J. K. \& Lee, Y.K. 2005. Effect of service orientation on job satisfaction, organizational commitment, and intention of leaving in a casual dining chain restaurant. International Journal of Hospitality Management 24, I7I-I93.

Kosar, Lj. (20O2). Hotelijerstvo (Hotel Industry). Belgrade: College of Hotel Management.

Kottke, J. L. and Sharafinski, C. E. I988. Measuring perceived supervisory and organizational support. Educational and Psychological Measurement, 48, IO75-IO79

Lahey, M.A. (1984). Job Security: its meaning and measure. Unpublished Doctoral Dissertation, Kansas State University, Kansas.

Lawler L., and Hackman, J. R. (I97I). Corporate profits and employee satisfaction: Must they be in conflict? California Management Review, I4(I), 46.

Lawler, E. E. andSuttle, L. (1973). Expectancy theory and job behavior. Organizational Behavior and Human Performance, 9, 482-5O3.

Lee, Y.K., Park, D.H. and Yoo, D. (I999). The structural relationships between service orientation, mediators, and business performance in Korea hotel firms. Asia Pacific Journal of Tourism Research, 4 (I), 59-7O.

Lucas Jr., G. H., Parasuraman, A., Davis, R. A., and Enis, B. M. (I987), An empirical study of sales force turnover. Journal of Marketing, 5I, 34-59.

Lytle, R.S., I994. Service orientation, market orientation, and performance: an organizational culture perspective. Doctoral Dissertation, Arizona State University, Arizona. 
Lytle, R.S., Hom, P.W. and Mokwa, M.P. I998. SERV*OR: a managerial measure of organizational service orientation. Journal of Retailing, 74 (4), 447-454.

Mars, G., and Nicod, M. (I984). The world of waiters. London: Allen and Unwin

Mobley, W.H. 1977. Intermediate linkages in the relationship between job satisfaction and employee turnover. Journal of Applied Psychology 62 (2), 237-240.

Nikolić, M. 2006. Uloga menadžmenta hotela u preispitivanju procesa rada (The role of hotel management in review of work process). Turizam IO, I76-I78.

O'Connor, S. J., Trinh, H. Q. and Shewchuk, R. M. (2000). Determinants of service orientation among medical students. Oxford, OH: Miami University Farmer School of Business.

Odom, R. Y, Boxx, W. R. and Dunn, M. G. I990. Organizational culture, commitment, satisfaction and cohesion. Public Productivity and Management Review I4 (2), I57-I68.

Rhoades, L., Eisenberger, R. (20O2). Perceived organizational support: A review of the literature. Journal of Applied Psychology, 87(4), 698-7I4.

Schneider, B. and Bowen, D.E. (1985). Employee and customer perceptions of service in banks: Replication and extension. Journal of Applied Psychology, 7O(3), 423-433.

Shaw, J.D. I999. Job satisfaction and turnover intentions: the moderating role of positive affect. The Journal of Social Psychology I39 (2), 242-244.

Staw, B. M., Bell, N. E., and Clausen, J. A. (I986). The dispositional approach to job attitudes: A lifetime longitudinal test. Administrative Science Quarterly, 3I, 56-77.

Sujan, H. (I986). Smarter versus harder: An exploratory attributional analysis of salespeople's motivation. Journal of Marketing Research, 23, 4I-49.

Teas, R. K. (1983). Supervisory behavior, role stress, and the job satisfaction of industrial salespeople. Journal of Marketing Research, 2O, 84-9I.

http://www.turizam.merr.gov.rs/index.php/yu/dokumenta/sektor-za-turizam/kategorizacija 